\title{
Two new species of Scaptotrigona Moure, 1942 from the Amazon forest (Hymenoptera: Apidae: Meliponini)
}

\author{
Registered on ZooBank: urn:Isid:zoobank.org:pub:A877CC45-9F41-40B4-A117-28ED73156AA5 \\ David Silva Nogueira ${ }^{1,2 \bowtie \odot}$, José Augusto dos Santos-Silva ${ }^{2}$, Matheus Mourão Carvalho ${ }^{\circ}$, Gislene Almeida \\ Carvalho-Zilse $^{4 \oplus}$, Rogério Marcos de Oliveira Alves ${ }^{4 \oplus}$ \& Marcio Luiz Oliveira ${ }^{5 \oplus}$ \\ 1. Instituto Federal de Educação, Ciência e Tecnologia do Amazonas (IFAM), Manaus, AM, Brazil. 2. Programa de Pós-Graduação em \\ Entomologia, Instituto Nacional de Pesquisas da Amazônia (INPA), Manaus, AM, Brazil. 3. Departamento de Zoologia da Universidade \\ de Brasília (DZUB-UnB), Brasília, DF, Brazil. 4. Grupo de Pesquisas em Abelhas, Instituto Nacional de Pesquisas da Amazônia (GPA- \\ INPA), Manaus, AM, Brazil. 5. Coordenação de Biodiversidade, Instituto Nacional de Pesquisas da Amazônia (INPA), Manaus, AM, \\ Brazil.
}

\section{EntomoBrasilis 15: e985 (2022)}

\begin{abstract}
The aim of this study was to describe Scaptotrigona nigrohirta sp. nov. and Scaptotrigona hylaeana sp. nov., in order to make their names valid, since at least one of these species has already been widely studied and cited, however, never been formally validated. Also, we have added some comparative notes among some species.
\end{abstract}

Keywords: Anthophila; bee; morphology; stingless bee; taxonomy.

\section{Edited by:}

Alberto Moreira Silva-Neto

\section{Article History:}

Received: 16.xii.2021

First Answer: 05.i.2022

Accepted: 11.i.2022

Published: 21.i.2022

\section{Corresponding author:}

David Silva Nogueira

乃dsnogueira90@gmail.com

\section{Funding agencies:}

\& Fundação de Amparo à Pesquisa do Estado do Amazonas (FAPEAM); Coordenação de Aperfeiçoamento de Pessoal de Nível Superior (CAPES).

\section{EntomoBrasillis} Update Check

\section{doi: 10.12741/ebrasilis.v15.e985}

$$
\text { (c) The Author(s) 2022. Published by }
$$
Entomologistas do Brasil

This article is published by Entomologistas do Brasil and licensed under Creative Commons Licence 4.0 (CC-BY) (c) (i)

\section{¿ Article Full Open Access}

The Neotropical genus Scaptotrigona Moure, 1942 is characterized by having bees with a projected scutellum and an uncut apex; mesonotum with fine, dense and strong punctuation; malar space, in general, greater than antennal socket diameter; with terga finely matte punctate (MOURE 1942). Despite this genus had been considered to be related to Nannotrigona Cockerell, 1922 (Moure 1942, 1951; SiLveIRA et al. 2002; Michener 1990, 2007), having as shared characters, for example, the punctuation of the head and mesosoma, the scutellum projected on the metanotum and the presence of a depression in the scutellum near the scutellum-scutellar suture, RASMUSSEN \& CAMERON (2010), using molecular characters in a Bayesian analysis, recovered Oxytrigona Cockerell, 1917 as its sister-group. However, another genus, Meliwillea Roubik, Lobo \& Camargo, 1997, with only one relictual species, was not included in RASMUSSEN \& CAMERON (2010) analysis but can be the most related genus by three synapomorphic characters: i. large gena (at the level of lower tangent orbital), ii. presence of long and sinuous hairs on venter, and iii. presence of tomentum on terga (RoubIK et al. 1997).

Scaptotrigona does not have its taxonomy revised and there are several new species to be described (Rasmussen \& Cameron 2010; Pedro 2014), consequently the identification of its species is confusing, mainly due to the fact that there may be species complexes that are difficult to separate (SIIVEIRA et al. 2002), even if they are widely used for breeding by indigenous people and stingless bees beekeepers in the Amazon (PoSEY 1986; CAMARgo \& Posey 1990; Venturieri \& Imperatriz-Fonseca 2000; Ferreira et al. 2020)

The aim of this study was to describe two new species of Scaptotrigona from the Amazon forest, since at least one of them is widely used in meliponiculture (POSEY 1986; CAMARGO \& Posey 1990; Barbosa-Costa et al. 2012; Barbosa-Costa \& Carvalho-Zilse 2013) and has been cited in the literature since POSEY (1982).

\section{MATERIAL AND METHODS}

All specimens studied belong to the Invertebrate Collection of the Instituto Nacional de Pesquisas da Amazônia (INPA, Manaus, Brazil) and Zoologische Staatssammlung München (ZSM, Munich, Germany). But four paratypes will be donated to collections (three of Scaptotrigona nigrohirta sp. nov. and one of Scaptotrigona hylaeana sp. nov. for each collection, presented in the section Material Examined): Museu Paraense Emílio Goeldi (MPEG - Belém, Pará, Brazil), Museu de Zoologia da Universidade de São Paulo (MZSP São Paulo, São Paulo, Brazil), Coleção Prof. J.M.F. Camargo, Universidade de São Paulo, Faculdade de Filosofia, Ciências e Letras (RPSP - Ribeirão Preto, São Paulo, Brazil) and Zoologische Staatssammlung München (ZSM, Munich, Germany).

In the material examined, data on each label were transcribed following the state or province in alphabetical order. In descriptions "S" was used for sterna and "T" for terga. Distribution records were obtained from data labels of the specimens, as well as from 
literature, e.g., CAMARGO \& PEDRO (2013), and for non-specific occurrences (such as states/provinces), we look for the coordinate in the vicinity of the centroid to build the map.

The morphological terminology follows CAMARGo et al. (1967), except for the denomination of metasoma (terga and sterna), which follows Michener (1990) and Silveira et al. (2002). Legs and respective podomeres are according to the segment, e.g., metatibia refers to the metathoracic tibia.

The subsequent citation is organized chronologically and followed an update of the data contained in CAMARGO \& PEDRO (2013), and we maintaned and add all publications that cited the species, even with different names.

Examination and photographs of specimens was performed using a Leica M205A stereomicroscope, coupled with a Leica DMC4500 and stacked using the software Leica Application Suite v4.10.0 Interactive Measurements, Montage.

\section{RESULTS AND DISCUSSION}

\section{Scaptotrigona nigrohirta sp. nov. Nogueira \& Santos-Silva}

urn:Isid:zoobank.org:pub:66BBD0DA-E731-4379-8B9B-D57F66CB6A63

Nannotrigona (Scaptotrigona) nigrohirta: POSEY 1982: 457 [nomen nudum, list]; POSEY 1983: 71 [nomen nudum, list]; CAMARGO \& PEDRO 2013 [nomen nudum, catalog, incertae sedis, citation].

Nannotrigona (Scaptotrigona) xanthotricha: CoImBRA JR. 1985: 66 [geographic record, folk name: yoidíter-éy].

Scaptotrigona nigrohirta: POSEY \& CAMARGO 1985: 250, 252, 254, 261, 266-268 [nomen nudum, nest entrance, behavior, habitat, figures 2D and 4A, folk names: imrê ñy kamrek, imrênhy-kamrek, "red imrê"]; POSEY 1986: 256, 261 [nomen nudum, habitat, folk name: imrê-ñy-kamrek]; CAMARGo \& POSEY 1990: $18,19,21-23,25,31,35,36$ [nomen nudum, nest entrance, behavior, habitat, folk name: imerê-ñy-kamrek, figures 2D and 4A]; CAMARGO \& ROUBIK 1991: 27 [nomen nudum, nest]; CAMARgo 1994: 53 [nomen nudum, behavior, nest]; KerR et al. 1996: 35 [nomen nudum, nest entrance, figure 3D]; VENTURIERI 1999: 94 [nomen nudum, geographic record, floral resource]; VENTURIERI \& IMPERATRIZ-FONSECA 2000: 356 [nomen nudum, geographic record, management, nest, behavior]; OLIVEIRA 2002: 616, 628 [nomen nudum, nest, folk name: cu-de-vaca, bui txashkaati]; CRUz-LANDIM et al. 2006: 169 [nomen nudum, class III glands size]; Cortopassi-LaURINo et al. 2006: 280 [nomen nudum, geographic records]; Françoso \& ARIAS 2013: 847 [nomen nudum, COI sequence KC853354]; REZENDE et al. 2019: $255,256,257,258,260,262,264,265,266$ [nomen nudum, geographic record, floral resource]; FerREIRA 2020: 46, 47, 57, $61,62,67$ [nomen nudum, geographic record, floral resource].

Trigona (Scaptotrigona) xanthotricha: BAUMGARTNER \& ROUBIK 1989: 16-19 [geographic record, behavior].

Scaptotrigona xanthotricha: BAUMGARTNER \& ROUBIK 1989: 14 [geographic record]; NATES-PARRA 2001: 240 [geographic record]; COSTA 2010: i-iii, vii-xxi, 1, 4-6, 13, 16, 18-20, 23, 26-28, 30, 32-34, 36, 38, 40-44, 47-50, 59-61, 65, 70-72, 74, 76, 79, 81, $83,84,86-88,100-102,109-111,114-126,128,134-136,139$, 140, 142-144, 146, 148-151, 153, 159 [behavior, nest entrance, honey, pollen and queen production, chapter 1 figures: 1 , 3-10; chapter 4 figures: 1-3]; Barbosa-Costa \& CarvalHo-ZILSE 2013: 8, 91-103 [biology, geographic record, figures 1, 2, 4]; CARVAlho-Zilse 2013: 21, 22 [nest entrance, figure 1D]; CostaNeto et al. 2016: 143 [geographic record, folk name: trombeta de macaco]; MAlA et al. 2020: 1378 [geographic record];

Scaptotrigona sp.n nigrohirta: DeLGADO \& VeLA 2012: 81,
82, 85 [nomen nudum, floral resource, geografic record, characteristics, figure $1 \mathrm{C}]$.

Scaptotrigona aff. xanthotricha: FERREIRA et al. 2020: 1-7 [as Scaptotrigona xanthotrica, sic (page 2), poisoning test, folk name: canudo]; PIREs et al. 2020: 59252, 59254, 59258, 59260, 59262 [geographic record, honey characters, folk name: canudo]; VIANA et al. 2021: 4 [as Scaptotrigona aff. xanthotricha, sic, geographic record, folk name: canudo];

Diagnosis: Bees in general yellowish brown with black terga with yellowish brown apical band and with or without yellowish brown maculations on T1 and T2. Head black with lower half (up to half of the antennal socket) depigmented and vitreous, as well as the clypeus and labrum. Very similar to S. xanthotricha Moure, 1950, except for the rounded shape on the posterior border of the metabasitarsus (Figure 2E). In general, it has dark brown to black hairs on the metabasitarsus and vertex. Area of the gena strongly carinated in the shape of two spines (Figure 2C).

\section{Description: Worker (Figures 1, 2A, 2C, 2E, 3B and 4A).}

Coloration: Integument predominantly yellowish-brown. Labrum, clypeus, radicle, malar area and supraclypeal area yellowish-brown. Gena yellowish-brown with superior area black. Mandible brown with apical half reddish-brown and with brown condyles. Scape yellowish-brown. Pedicel dark brown. Flagellum dark brown with brown in ventral view of F1 to F10. Pronotal lobe, propodeum, scutellum and axilla yellowish-brown. Mesepisternum yellowish-brown with a brown maculation on inferior area. Mesoscutum black. Legs yellowish-brown with metabasitarsus and other tarsomeres brown. Tegula yellowish vitreous. Pterostigma and wing venation brown. Wing membranes slightly smoky with microtrichia brown more abundant in the apical area of the Rs vein. T1 with vertical area yellowish-brown vitreous and discal area black with apical band yellowish-brown. T2-T6 black with apical band yellowish-brown. Sterna yellow.

Punctation: Integument predominantly punctate. Head and mesosoma shiny and punctate. Legs and sterna smooth and shiny with pilligera puntaction with rugose aspect. Terga matte.

Pubescence: Frons with yellow simple setae $(0.2 \mathrm{~mm})$. Malar area practically glabrous with very short setae $(0.03$ $\mathrm{mm})$. Basal area of scape with long, simple and yellowish setae $(0.10 \mathrm{~mm})$. Vertex with black long simple setae $(0.26 \mathrm{~mm})$. Clypeus and supraclypeal area in lateral view with decumbent yellow simple setae $(0.01 \mathrm{~mm})$. Labrum with yellow simple setae $(0.21 \mathrm{~mm})$. Coxae with whitish simple hairs: procoxa $(0.25 \mathrm{~mm})$, mesocoxa $(0.29 \mathrm{~mm})$ and metacoxa $(0.42 \mathrm{~mm})$. Mesocoxa and metacoxa with hairs with delicate crimped apex. Trochanters with whitish simple hairs with delicate crimped apex: protrochanter $(0.25$ $\mathrm{mm})$, mesotrochanter $(0.24 \mathrm{~mm})$ and metatrochanter $(0.37$ $\mathrm{mm})$. Basal area of profemur with whitish simple hairs with delicate crimped apex $(0.21 \mathrm{~mm})$, and short branched hairs $(0.07 \mathrm{~mm})$ and apical area with erect setae $(0.11 \mathrm{~mm})$ and very short branched hairs on ventral face of profemur $(0.04$ $\mathrm{mm})$. Basal area of mesofemur with whitish simple hairs with delicate crimped apex $(0.26 \mathrm{~mm})$, and short branched hairs $(0.05 \mathrm{~mm})$, and apical area with short erect brown setae $(0.07 \mathrm{~mm})$ and very short branched hairs on ventral face of mesofemur $(0.05 \mathrm{~mm})$. Metafemur with whitish hairs with delicate crimped apex on basal area $(0.09 \mathrm{~mm})$ and with long erect branched brown to black setae on apical area $(0.26$ $\mathrm{mm})$. Protibia $(0.24 \mathrm{~mm})$, mesotibia $(0.35 \mathrm{~mm})$ and metatibia $(0.36 \mathrm{~mm})$ with simple and branched black setae on posterior border. Corbicula area with long black setae with delicate crimped apex $(0.61 \mathrm{~mm})$. Probasitarsus with brown to black 


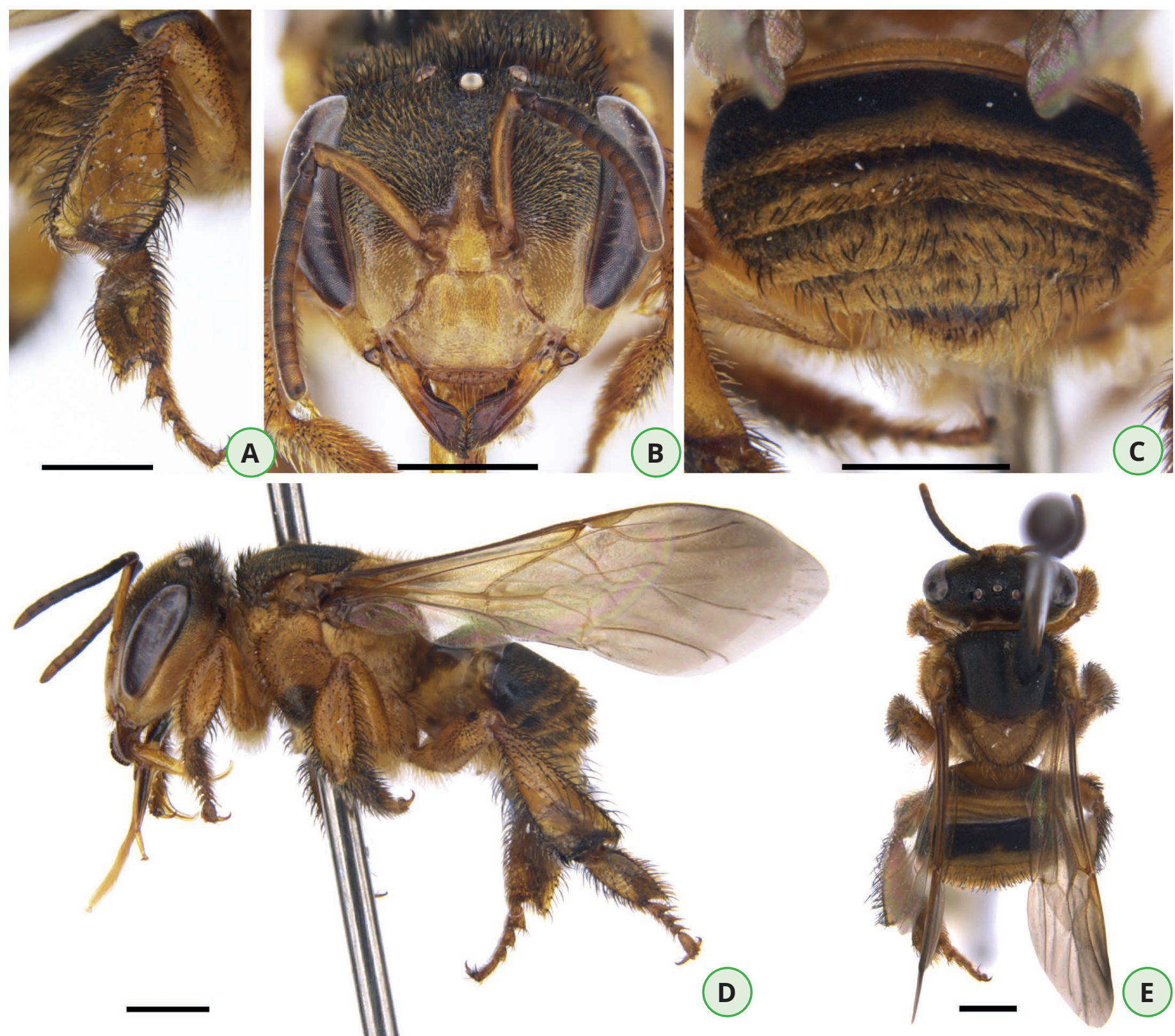

Figure 1. Holotype of Scaptotrigona nigrohirta sp. nov.. Metatibia and metabasitarsus (A), head in frontal view (B), metasoma in dorsalposterior view (C), body in lateral view (D) and body in dorsal view (E). Scales $0.5 \mathrm{~mm}(A$ and $B)$ and $1 \mathrm{~mm}(C, D$ and E). Source: authors.

simple setae $(0.33 \mathrm{~mm})$. Mesobasitarsus with brown to black simple and branched setae and branched hairs $(0.26$ $\mathrm{mm})$. Metabasitarsus with simple brown and black setae (0.27 mm). Mesoscutum with decumbent simple $(0.05 \mathrm{~mm})$ and branched $(0.08 \mathrm{~mm})$ yellowish hairs and anterior area with erect simple and branched black setae $(0.20 \mathrm{~mm})$. Mesoscutellum with simple (or with branch) yellow and black setae $(0.37 \mathrm{~mm})$. Sides of propodeum with long simple yellowish hairs $(0.22 \mathrm{~mm})$ and short branched hairs $(0.10$ $\mathrm{mm})$. Mesepisternum with simple erect yellowish setae $(0.14$ $\mathrm{mm}$ ) and branched decumbent yellowish hairs $(0.05 \mathrm{~mm})$. Inferior area of mesepisternum with simple yellowish hairs with delicate crimped apex $(0.35 \mathrm{~mm})$. Metepisternum with very abundant decumbent yellowish branched hairs $(0.10$ $\mathrm{mm})$. T1 with decumbent yellowish branched hairs $(0.05$ $\mathrm{mm})$. T2 with decumbent yellowish branched hairs $(0.06 \mathrm{~mm})$ and long simple and branched black setae $(0.15 \mathrm{~mm})$. T3 with branched black setae $(0.19 \mathrm{~mm})$ and simple decumbent branched yellowish hairs $(0.11 \mathrm{~mm})$. T4 with branched black setae $(0.24 \mathrm{~mm})$ and branched yellowish hairs $(0.14 \mathrm{~mm})$. T5 with branched and simple brown to black setae $(0.20 \mathrm{~mm})$ and branched yellowish hairs $(0.08 \mathrm{~mm})$. T6 with branched and simple brown to black setae $(0.21 \mathrm{~mm})$ and decumbent branched yellowish hairs $(0.08 \mathrm{~mm})$. Sterna with abundant long yellowish hairs with delicate crimped apex $(0.42 \mathrm{~mm})$.
Structures: Body length $6.06 \mathrm{~mm}$. Head 1.24x wider than long $(2.24 \mathrm{~mm}: 2.79 \mathrm{~mm}$, length and width, respectively). Forewing length $5.77 \mathrm{~mm}$. Length of compound eye $3.82 x$ breadth $(1.57 \mathrm{~mm}: 0.41 \mathrm{~mm}$, length and width of the compound eye, respectively). Inner orbits concave, converging downwards $(1.76 \mathrm{~mm}$ : $1.64 \mathrm{~mm}$, superior and inferior interorbital distance, respectively). Maximum interorbital distance greater than the length of the eyes (1.89 $\mathrm{mm}$ : $1.57 \mathrm{~mm}$ ). Malar area $2.12 \mathrm{x}$ of the flagellum diameter $(0.34 \mathrm{~mm}: 0.16 \mathrm{~mm})$. Clypeus with width $1.85 x$ its length $(0.7$ $\mathrm{mm}: 1.3 \mathrm{~mm}=$ length and width of clypeus respectively). Clypeus-ocellar distance $1.31 \mathrm{~mm}$. Alveolorbital distance equal to interalveolar distance $(0.50 \mathrm{~mm})$. Vertex slightly convex. Ocellorbital distance slightly greater than interocellar distance $(0.52 \mathrm{~mm}$ : $0.50 \mathrm{~mm})$. Scape length $6.73 x$ its width $(1.01 \mathrm{~mm}: 0.15 \mathrm{~mm})$. Flagellum width slightly greater than the pedicel width $(0.16 \mathrm{~mm}: 0.13 \mathrm{~mm})$. Mandible with the second tooth wider than the first. Mesotibial spur $0.26 \mathrm{~mm}$ long. Metatibia with triangular corbicula; length of metatibia $2.1 \mathrm{x}$ its width ( $2 \mathrm{~mm}: 0.95 \mathrm{~mm}$ ). Metabasitarsus 1.78x longer than broad (1.14 mm: $0.64 \mathrm{~mm}$ ) and with posterior bord angled and projected. Intertegular distance $1.82 \mathrm{~mm}$. With 7 hamuli on posterior wing. Mesoscutellum 1.27x wider than long (0.79 mm: $1.27 \mathrm{~mm}$, length and width, respectively). 
Etymology and remarks: This species has been widely cited in the literature, however, it has never been officially published to this moment. It was being described by Jesus Santiago Moure, however, he did not have the opportunity to publish it before his death. The specific epithet given by him was "nigrohirta", which we decided to keep in his honor. The etymology comes from Latin which means "black erect setae", and probably alludes to the simple setae present in the vertex, basitarsi and terga of most specimens. When we are studying nest material, we noticed that this character varies, as there are individuals with yellowish-brown setae in these areas. Also, this name can be an allusion to the setae present in the anterior portion of the mesoscutum, as they are black and elongated in relation to the setae of the same region in $S$. xanthotricha, which are shorter and brownish.

Several studies that used other species names such as $S$. xanthotricha (or S. aff. xanthotricha) to refer to S. nigrohirta sp. nov. (e.g., COIMBRA JR. 1985; BAUMgartner \& ROUBIK 1989; NATESParra 2001; Costa 2010; Carvalho-Zilse 2013; Barbosa-Costa \&
Carvalho-Zilse 2013; Ferreira et al. 2020; Maia et al. 2020; Pires et al. 2020; VIANA et al. 2021), however, it is evident that they are distinct species, since the T1 of S. nigrohirta sp. nov. it has abundant branched hairs while $S$. xanthotricha are sparse (Figure 2A and B), the shape of the metabasitarsus is different, with the middle posterior border of $S$. xanthotricha is angled and S. nigrohirta sp. nov. is rounded (Figure 2E, F and G), in addition to the $\mathrm{M}$ and $\mathrm{Cu} 1$ veins of the forewing being strong in S. nigrohirta sp. nov. (Figure $3 \mathrm{~A}, \mathrm{~B}$ and C). In relation to $S$. pectoralis (Dalla Torre, 1896), the yellow depigmentation on the forehead is lower, until the midline of the antennal socket in S. nigrohirta sp. nov. (Figure 1B and 2D) and S. xanthotricha (Figure 3D).

Based on the distribution of species presented by CAMARGO \& Pedro (2013) and Pedro (2014), on the genetic support presented by DUARTE et al. (2014) and in the data presented in this present study, we define here that the distribution of occurrence of $S$. xanthotricha is restricted to areas of Atlantic forest and S. nigrohirta sp. nov. to areas of the Amazon
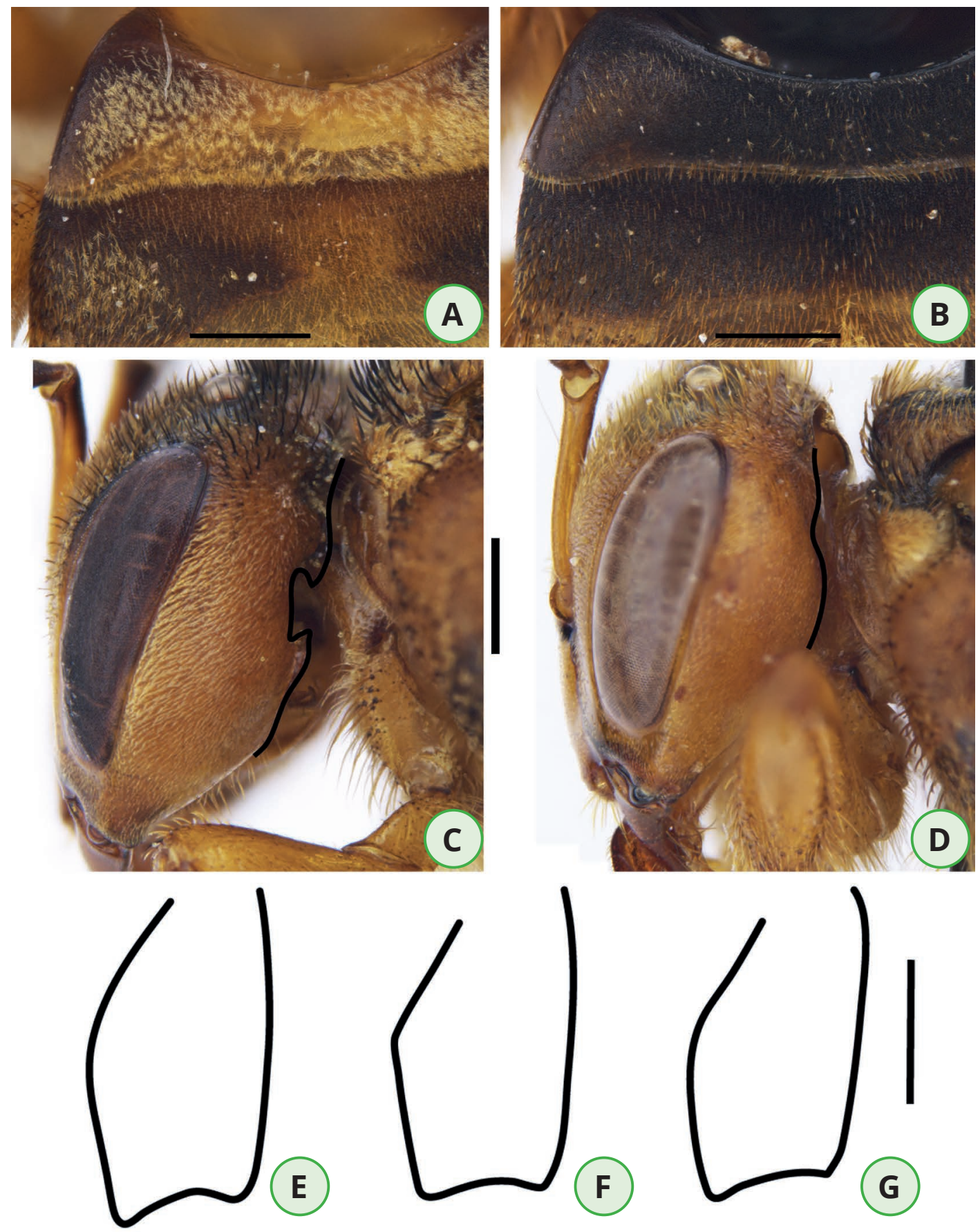

Figure 2. Structures of Scaptotrigona Moure, 1942. T1 and T2 of S. nigrohirta sp. nov. (A) and S. xanthotricha Moure, 1950 (B). Head in lateral view of S. nigrohirta sp. nov. (C) and S. pectoralis (Dalla Torre, 1896) (D). Metabasitarsus of S. nigrohirta sp. nov. (E), S. xanthotricha (F) and S. pectoralis (G). Scales: $0.5 \mathrm{~mm}(\mathrm{~A}, \mathrm{~B}, \mathrm{C}$ and $\mathrm{D})$ and $0.25 \mathrm{~mm}(\mathrm{E}, \mathrm{F}$ and $\mathrm{G})$. Source: authors. 

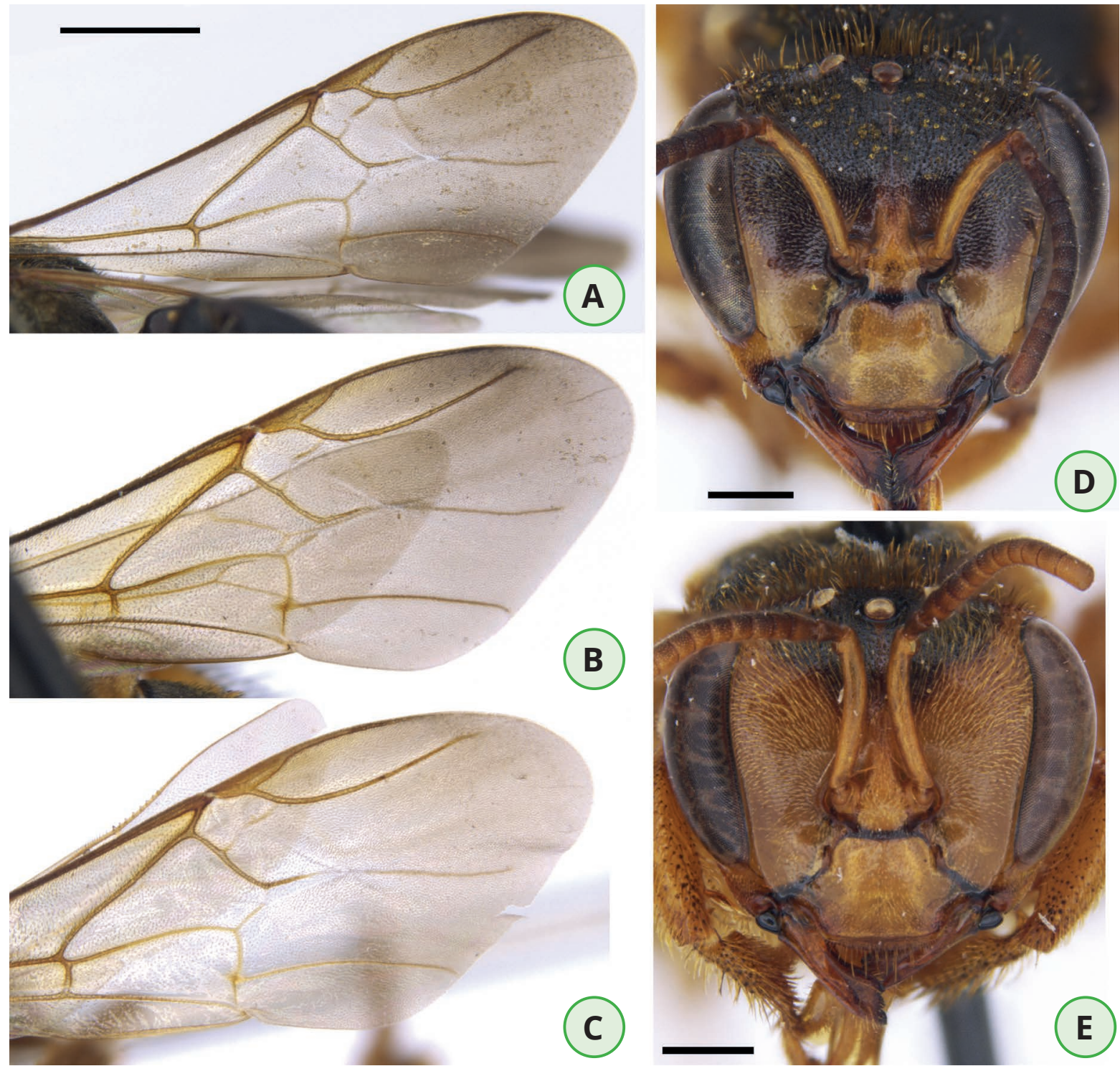

Figure 3. Forewing and head of Scaptotrigona Moure, 1942 species. Forewing of S. hylaeana sp. nov. (A), S. nigrohirta sp. nov. (B), and S. xanthotricha Moure, 1950 (D). Head of S. xanthotricha (D) and S. pectoralis (Dalla Torre, 1896). Scales $1 \mathrm{~mm}(\mathrm{~A}, \mathrm{~B}$, and C) and $0.5 \mathrm{~mm}$ (D and E). Source: authors.

rainforest.

Furthermore, S. nigrohirta sp. nov. can be distinguished from S. fulvicutis (Moure, 1964), which is the other yellow Amazonian species, because $S$. fulvicutis has a yellow mesoscutum, the face in frontal view with strong punctuation and clypeus with abundant setae, while S. nigrohirta sp. nov. has dark brown to black mesoscutum, face with punctuation sparse and the clypeus practically glabrous, with sparse and very short setae.

Variations: Some individuals from Campo Novo (Rondônia, Brazil), Barcelos and Jaú National Park (Amazonas, Brazil) have a yellow (depigmented) spot on the forehead above the upper socket line, as well as in S. pectoralis (Figure 2D). An individual from Terra Indígena São Marcos-Guaribas (Roraima, Brazil) has a black spot at the base of the clypeus. Some individuals from Belterra (Pará, Brazil) have two yellow triangles joined by a vertex at T2 (Figure 2A).

A label of one of the bees from Campo Novo (Rondônia, Brazil) was handwritten "Scaptotrigona nigrohirta var. xanthina in litt.", however, without identifying who wrote. And another from the Toototobi indigenous area (Yanomami indigenous people, Barcelos, Amazonas, Brazil) written "N. (Scaptotrigona) chorerraensis Schwarz MS, Camargo 1982Det.", but this name was never formally published for the species.

Biological notes: Bees are highly defensive and build the nest entrance in a cylindrical shape (Figure 4A) (POSEY \& CAMARGO
1985; Costa 2010; Barbosa-Costa \& Carvalho-Zilse 2013).

Geographical distribution (Figure 6): Brazil (Acre, Amazonas, Maranhão, Pará, Rondônia, Roraima), Peru (Nauta).

Examined Material: S. nigrohirta sp nov.: Holotype: worker. Label data: BRA, AM, Manaus, 26.xi.2021, INPA 1, ninho portaria. Paratypes (273), workers. BRAZIL: Amazonas: 2 (INPA), Brasil - AM, PARNA do Jaú, 14-20 Out 2003, M.L. Oliveira \& J.A. Cunha leg., Em ninho / Scaptotrigona nigrohirta sp.n Moure, MS, Det. Camargo, 2009; 1 (INPA), BRASIL. Amazonas. Serra do Aracá, Acampamento base. 108 m.a. $00^{\circ} 52^{\prime} 26.4^{\prime \prime} \mathrm{N} / 63^{\circ} 27^{\prime} 18.0^{\prime \prime} \mathrm{W}, 09 / \mathrm{viii} / 2007$. ninho, M.L. Oliveira \& A. S. Filho leg. / Scaptotrigona nigrohirta sp.n Moure, MS, Det. Camargo, 2009; 6 (INPA), RPSP 814c / Samaúma, rio Demini, AM, Brasil, 24.VII.1999, 6246’W. 00²2'S, Camargo, Pedro, Mazucato / Scaptotrigona sp.n., Camargo \& Moure, MS, Det. Camargo, 2000 / Scaptotrigona nigrohirta sp.n Moure, MS, Det. Camargo, 2007; 5 (INPA), BRA, AM, Iranduba, Sítio Hélio, 08.xi.2021, Carvalho-Zilse e eq. (12); 1 (INPA), BRASIL AMAZONAS, LÁBREA - RIO ITUXI, 1 - X - 76, EDUARDO PRETAS / Scaptotrigona nigrohirta sp.n Moure, MS, Det. Camargo, 2009; 3 (INPA), BRA, AM, Manaus, 19.vii.2019, INPA 1, D. Nogueira leg.; 63 (INPA), BRA, AM, Manaus, 26.xi.2021, INPA 1, ninho biblioteca; 35 (INPA), BRA, AM, Manaus, 26.xi.2021, INPA 1, ninho portaria; 3 (RPSP) idem; 3 (MZSP) idem; 3 (MPEG) idem; 3 (ZSM) idem; 1 (INPA), BRA, AM, Maués, Sítio Dedeco, 27.x.2021, Carvalho-Zilse e eq. (15); 3 (INPA), BRA, AM, Maués, Sítio Dedeco, 27.x.2021, Carvalho-Zilse e eq. (24); 5 (INPA), 

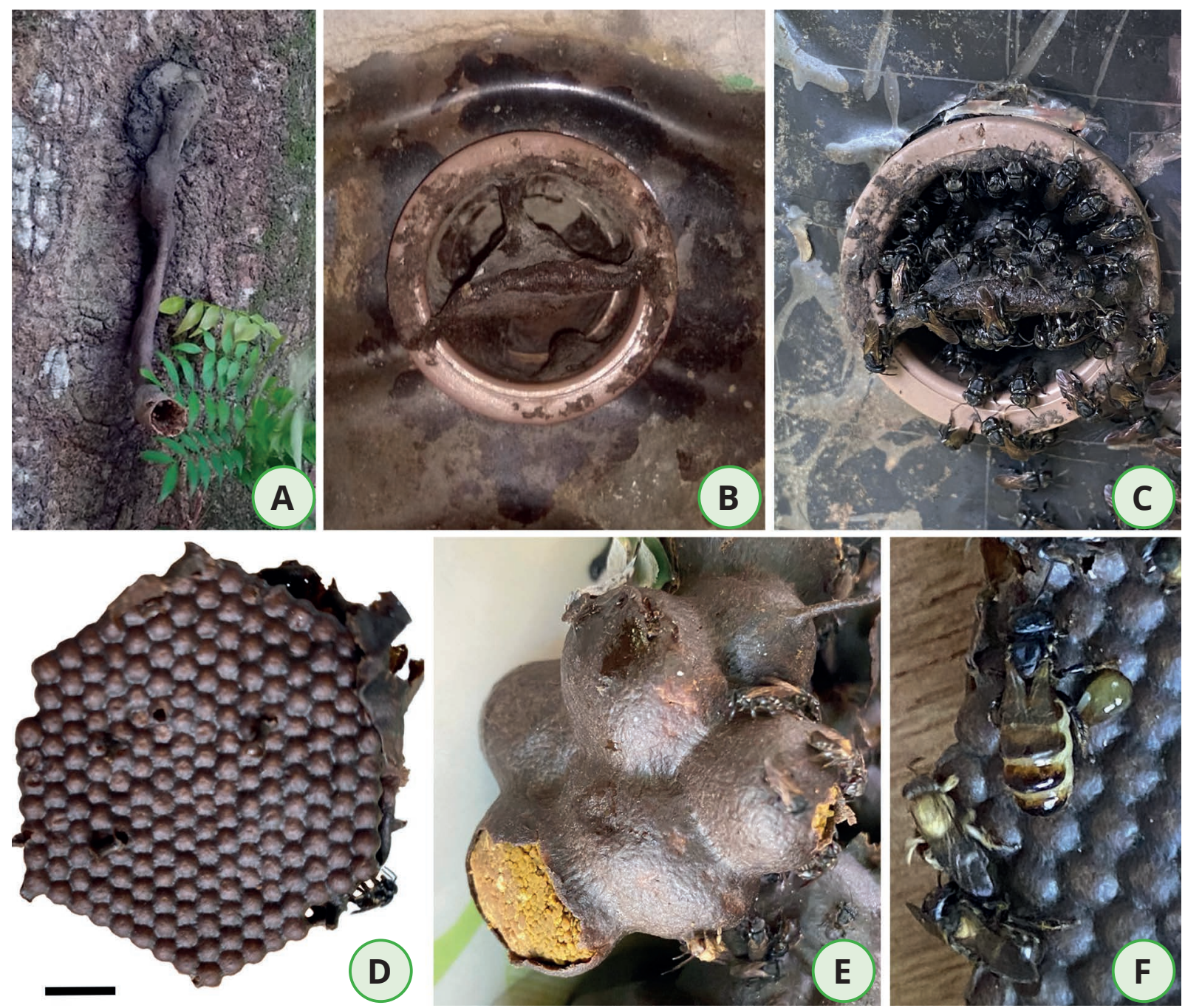

Figure 4. Nest structures of Scaptotrigona Moure, 1942 species. Nest entrance of Scaptotrigona nigrohirta sp. nov. in a trunk in Instituto Nacional de Pesquisas da Amazônia (INPA, Manaus, Amazonas, Brazil) (A). Nest entrance of Scaptotrigona hylaeana sp. nov. in a trap-nest in Scientific Meliponary of Grupo de Pesquisas em Abelhas from INPA (Manaus, Amazonas, Brazil) (B and C). Brood comb in superior view (D), food pots (E) and queen (F) of S. hylaeana sp. nov.. Scale bar 1 centimeter. Source: authors.

BRA, AM, Maués, Sítio Dedeco, 27.x.2021, Carvalho-Zilse e eq. (28); 3 (INPA), RPSP 803c / Samaúma, rio Daarã, AM, BRASIL

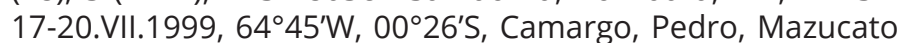
/ Scaptotrigona sp.n., Camargo \& Moure, MS, Det. Camargo, 2000 / Scaptotrigona nigrohirta sp.n Moure, MS, Det. Camargo, 2007; 6 (INPA), RPSP 766c / Plano, rio Negro, AM, BRASIL 0709.VII.1999, 6559'W. 00¹8'S, Camargo, Pedro, Mazucato / Scaptotrigona sp.n., Camargo \& Moure, MS, Det. Camargo, 2000 / Scaptotrigona nigrohirta sp.n Moure, MS, Det. Camargo, 2007; Pará: 2 (INPA), BRASIL Pará. Santarém.V, Alter do Chão. 18/VIII /2002, Glória Assis. leg. / Scaptotrigona nigrohirta sp.n Moure, MS, Det. Camargo, 2007; 3 (INPA), BRASIL, Pará, Alter do Chão. Ilha Campo. 24.ix.1989. U.C. Barbosa / Scaptotrigona nigrohirta sp.n Moure, MS, Det. Camargo, 2007; 6 (INPA), BRASIL, PA, Belterra, FLONA Tapajós, $100 \mathrm{~m}, 02^{\circ} 36^{\prime} 15^{\prime \prime} \mathrm{S}$ -

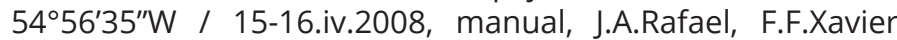
$\mathrm{F}^{\circ}$ / Scaptotrigona nigrohirta sp.n Moure, MS, Det. Camargo, 2009; Rondônia: 107 (INPA), Brasil Rondonia, Ig. [Igarapé] Tracoazinho, Reg. CpoNovo [Campo Novo] / 5 viii 1985, V. Py.Daniel, L Aquino / Scaptotrigona nigrohirta sp.n Moure, MS, Det.Camargo,2007; 2 (INPA), BRASIL: Rondônia, Vilhena, 22 vii - 5 viii 1983, F.J.A. Peralta / 124-c / Scaptotrigona nigrohirta sp.n Moure, MS, Det. Camargo, 2007; Roraima: 6 (INPA), Brasil, Roraima, 23-à 28-II-2003 / M.L.Oliveira \& S.J.R. Silva leg. A.I. São Marcos Guaribas, Em Ninho / Scaptotrigona nigrohirta sp.n Moure, MS, Det. Camargo, 2009.

S. pectoralis (36): COSTA RICA: San José: 34 (ZSM), Costa Rica Pr San José, Villa Lapas b. Tarcoles, Trockenwald 50 m, N945'326" W64³6'511", 18.04.2003 1. M. Kraus / Scaptotrigona pectoralis Det. D. Nogueira, 2021; 1 (ZSM), idem except: 19.04.2003; MEXICO: Chiapas: 1 (INPA), Mex, Chis, Jaltenango Paz, 886 m, 15,78 N; 92,62 W, 3/11/2017, Philippe Sagot / [verse] Scapec $q$ / [verse] Scaptotrigona pectoralis $q$ det. Sagot Ph. 2017.

S. xanthotricha (24): BRAZIL: Bahia: 1 (INPA), BRA, Bahia, Salvador, UFBA, 23.ix.2019; 1 (INPA), BRA, Bahia, Salvador, UFBA (Ondina), 11.iv.2013 / Scaptotrigona xanthotricha Moure, 1950, Det. D. Nogueira, 2019; Minas Gerais: 1 (INPA), Reinventário EPDA de Peti, 9779 - 28895 / São Gonçalo do Rio Abaixo MG, BRASIL 23/09/2003, N. G. F o n s e c a / Scaptotrigona xanthotricha (Moure, 1950), L. M. Santos, det. 2006; 17 (INPA), BRA, Minas Gerais, Viçosa, UFV Apiário, 17.ix.2019 / Scaptotrigona xanthotricha Moure, 1950, Det. D. Nogueira, 2019; São Paulo: 4 (ZSM), Brasilien São Paulo, v. Ihering / [verse] Trigona dorsalis, 1913 Friese det., Ym. [?] / Scaptotrigona xanthotricha, Det. D. Nogueira, 2021.

S. fulvicutis (16): BRAZIL: Amazonas: 1 (INPA), BRASII. Amazonas. Itacoatirara. AM-010. km 215. Faz Aruana. 0302S / 5850W. 21.viii.1991 F.J.Peralta / Scaptotrigona fulvicutis (Moure, 1964) Det. Camargo, 2001; 1 (INPA), BRASIL: Amazonas 60 Km.N.Manaus Fazenda Esteio ZF-3 Km-23 7-5-90 M.L.Oliveira / 2150 / Scaptotrigona fulvicutis (Moure, 1964) Det. Camargo, 2007; 1 (INPA), idem except: 23-8-90 / 2692; 1 (INPA), idem except: 4-6-90 / 2287; 1 (INPA), idem except: 27-11-90 / 0893; 1 (INPA), idem except: 12-3-90 / 1893; 1 (INPA), idem except: 7-4-90 / 2168; 1 (INPA), idem except: 03-4-90 / 2046; 1 (INPA), idem except: 23-2-90 / 1730; 1 (INPA), LO-1 500m / Brasil. Amazonas REBio Uatumã 29-III-2008 Presidente Figueiredo A. C. O. Araújo \& H.F. Guarlento / Scaptotrigona 
fulvicutis (Moure, 1964) Det. Camargo, 2009; Pará: 6 (INPA), BRASIL. Pará Oriximiná. Porto Trombetas Platô Avião 12/ II/2008 0554685/9806548-UTM Y. Antonin, M.L. Oliveira leg / Scaptotrigona fulvicutis (Moure, 1964) Det. Camargo, 2009.

\section{Scaptotrigona hylaeana sp. nov. Nogueira \& Santos-Silva}

urn:Isid:zoobank.org:pub:C0963946-273F-4ED2-8144-3BC095577F3C

Diagnosis: This species is distinguished by being shorter body length when compared to other known species with black integument (S. tubiba (Smith, 1863) or S. postica (Latreille, 1807), for example), having short setae on the forehead with an appearance velvety, mesosoma with short, sparse setae, finely matte-punctate integument of the clypeus and 3rd cell rs-m (between the second and third submarginal cell) vestigial (Figure 3A) (absent in S. nigrohirta sp. nov. and S. xanthotricha (Figure 3B, 3C).

Description: Worker (Figures 3A, 4B-F and 5).
Coloration: Integument predominantly dark brown to black. Labrum brown. Clypeus black with sides reddish-brown. Malar area, supraclypeal area and gena dark brown to black. Paraocular area, mandible and condyles reddish-brown. Radicle yellowish-brown. Scape dark brown with 1/5 basal yellowish-brown and apical band brown. Pedicel, flagellum and pronotal lobe dark brown. Mesosoma dark brown to black. Legs dark brown to black. Tarsomeres dark brown. Pterostigma and wing venation brown. Wing membranes slightly smoky with microtrichia brown more abundant in the apical area of the Rs vein. Metasoma dark brown to black.

Punctation: Integument predominantly punctate. Head matte and punctate with shiny areas on clypeus, malar space and paraocular area. Mesosoma matte and punctate. Legs and sterna smooth and shiny with pilligera puntaction with rugose aspect. Terga matte.

Pubescence: Frons with yellow very short simple setae $(0.03$ $\mathrm{mm})$. Malar area practically glabrous with very short setae

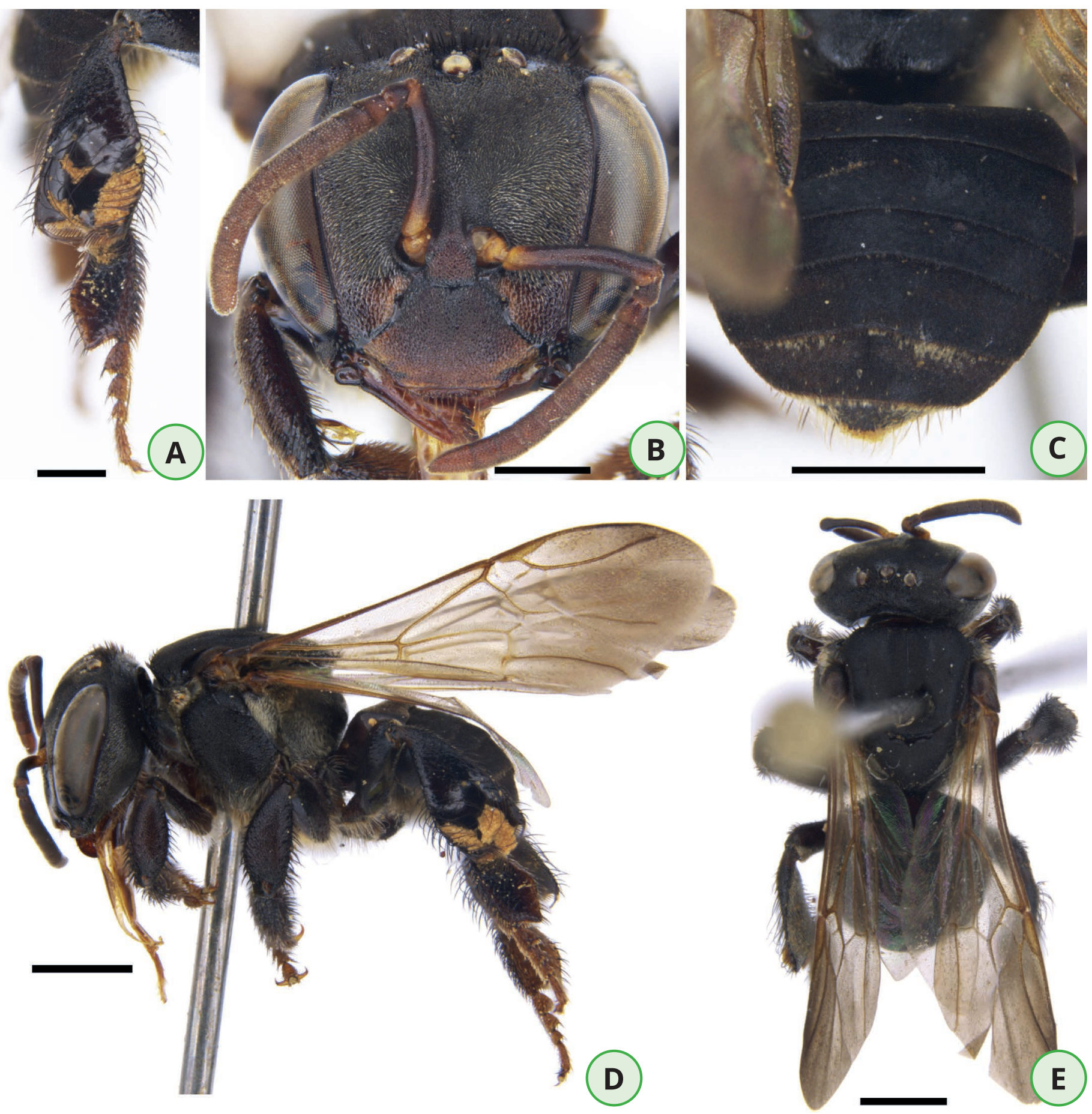

Figure 5. Holotype of Scaptotrigona hylaeana sp. nov.. Metatibia and metabasitarsus (A), head in frontal view (B), metasoma in dorsal view (C), body in lateral view (D) and body in dorsal view (E). Scales $0.5 \mathrm{~mm}(A$ and $B)$ and $1 \mathrm{~mm}(C, D$ and E). Source: authors. 
(0.01 mm). Scape, clypeus and supraclypeal area glabrous. Vertex with black long simple setae $(0.12 \mathrm{~mm})$ or with one branch. Labrum with brown simple setae $(0.17 \mathrm{~mm})$. Coxae with whitish simple hairs: procoxa $(0.14 \mathrm{~mm})$, mesocoxa $(0.15$ $\mathrm{mm}$ ) and metacoxa (0.19 $\mathrm{mm})$. Mesocoxa and metacoxa with hairs with delicate crimped apex. Trochanters with whitish simple hairs with delicate crimped apex: protrochanter $(0.19$ $\mathrm{mm})$, mesotrochanter $(0.25 \mathrm{~mm})$ and metatrochanter $(0.27$ $\mathrm{mm})$. Basal area of profemur with whitish simple hairs with delicate crimped apex $(0.16 \mathrm{~mm})$, and apical area with simple setae $(0.09 \mathrm{~mm})$. Basal area of mesofemur with whitish simple hairs with delicate crimped apex $(0.24 \mathrm{~mm})$, and apical area with simple brown setae $(0.09 \mathrm{~mm})$. Basal area of metafemur with whitish hairs with delicate crimped apex $(0.08 \mathrm{~mm})$ and with erect simple black setae on apical area $(0.06 \mathrm{~mm})$. Protibia $(0.21 \mathrm{~mm})$, mesotibia $(0.20 \mathrm{~mm})$ and metatibia $(0.24$ $\mathrm{mm}$ ) with simple black setae on posterior border. Corbicula area with long black setae with delicate crimped apex $(0.64$ $\mathrm{mm})$. Probasitarsus $(0.22 \mathrm{~mm})$, mesobasitarsus $(0.18 \mathrm{~mm})$ and metabasitarsus $(0.18 \mathrm{~mm})$ with simple black setae. Mesoscutum practically glabrous, with some simple black setae on anterior area of disc $(0.10 \mathrm{~mm})$. Mesoscutellum with simple black setae $(0.11 \mathrm{~mm})$. Sides of propodeum with long simple yellowish hairs $(0.22 \mathrm{~mm})$ and short branched hairs $(0.03 \mathrm{~mm})$. Mesepisternum with sparse simple erect yellowish setae $(0.05 \mathrm{~mm})$. Inferior area of mesepisternum with simple whitish hairs with delicate crimped apex $(0.31$ $\mathrm{mm})$. Metepisternum with very abundant decumbent whitish branched hairs $(0.03 \mathrm{~mm})$. T1 with decumbent yellowish branched hairs $(0.02 \mathrm{~mm})$. T2-T5 practically glabrous with sparse yellowish hairs $(0.02 \mathrm{~mm})$. Basal area of T5 with some branched hairs $(0.01 \mathrm{~mm})$. T6 with simple yellowish setae $(0.15 \mathrm{~mm})$ and sparse branched hairs $(0.02 \mathrm{~mm})$. Sterna with abundant long yellowish hairs with delicate crimped apex $(0.32 \mathrm{~mm})$.

Structures: Body length $4.88 \mathrm{~mm}$. Head 1.17x wider than long (1.86 mm: $2.19 \mathrm{~mm}$, length and width, respectively). Forewing length $4.78 \mathrm{~mm}$. Length of compound eye 3.86x breadth (1.39 mm: $0.36 \mathrm{~mm}$, length and width of the compound eye, respectively). Inner orbits concave, converging downwards $(1,32 \mathrm{~mm}: 1.21 \mathrm{~mm}$, superior and inferior interorbital distance, respectively). Maximum interorbital distance greater than the length of the eyes $(1.46 \mathrm{~mm}: 1.39 \mathrm{~mm})$. Flagellum diameter $1.14 \mathrm{x}$ of the malar area $(0.16 \mathrm{~mm}: 0.14 \mathrm{~mm})$. Clypeus with width $1.88 \mathrm{x}$ its length $(0.54 \mathrm{~mm}: 1.02 \mathrm{~mm}=$ length and width of clypeus respectively). Clypeus-ocellar distance $1.14 \mathrm{~mm}$. Alveolorbital distance greater than interalveolar distance (0.35 mm: $0.22 \mathrm{~mm}$, alveolorbital distance and interalveolar distance, respectively). Vertex slightly convex. Interocellar distance greater than ocellorbital distance $(0.45 \mathrm{~mm}: 0.30$ $\mathrm{mm})$. Scape length $7.08 \mathrm{x}$ its width $(0.85 \mathrm{~mm}$ : $0.12 \mathrm{~mm})$. Flagellum width slightly greater than the pedicel width $(0.16$ $\mathrm{mm}: 0.13 \mathrm{~mm}$ ). Mandible with the first tooth similar to the second. Mesotibial spur $0.22 \mathrm{~mm}$ long. Metatibia with triangular corbicula; length of metatibia $2.2 x$ its width $(1.65$ $\mathrm{mm}: 0.74 \mathrm{~mm})$. Metabasitarsus $1.45 x$ longer than broad $(0.89$ $\mathrm{mm}: 0.61 \mathrm{~mm}$ ) and with posterior bord angled and projected. Intertegular distance $1.42 \mathrm{~mm}$. With 7 hamuli on posterior wing. Mesoscutellum 1.55x wider than long $(0.87 \mathrm{~mm}: 1.56$ $\mathrm{mm}$, length and width, respectively).

Etymology and remarks: This is one of the new species left separated in the collection of the Instituto Nacional de Pesquisas da Amazônia (INPA) by João Maria Franco de Camargo before his death, and the reason why we decided to describe it was because a swarm spontaneously nested in a trap-nest in the Scientific Meliponary of Grupo de Pesquisas em Abelhas from INPA (Manaus, Amazonas, Brazil) (Figure 4B and $\mathrm{C}$ ).

We decided to keep the name "hylaeana" in memory of
Camargo, but the etymology seems to be in homage to the Amazon equatorial forest, also known by naturalists Alexander von Humbolt (1769-1859) and Aimé Bonpland (1773-1858) as "Hyleae".

Variations: The three workers from Ilha de Maracá (Roraima, Brazil) studied differ from the others in that they have a large part of the integument slightly lighter, stained black, mainly the metanotum which is pale yellow, the erect setae of T6 are yellowish-brown in contrast to the black setae of specimens of the type locality, this pattern is repeated, for example, in the erect black setae mixed with white pubescence around the propodeal spiracle; the sterna pubescence is pale yellow in the Roraima specimens have the apical band of T4-T5 continuous, unlike the typical form which has slightly yellowish pubescence on sterna and apical bands of T4-T5 that are clearly interrupted in the median region.

Biological notes: When workers are handled, they fly around the enemy but do not attack, even when they are provided with a lot of stored honey.

They do not build cylindrical nest entrance as is common in other Scaptotrigona species. Its entrance is constructed of dark-colored cerumen in a circular shape, measuring $3.5 \mathrm{~cm}$ in diameter, with a central diagonal division more pronounced than the edges of the circle, with no airstrip (Figure 4B and C). Guard bees are around the entrance landing on the substrate (Figure 4C). The brood comb is horizontal shape (Figure D). This species produces a lot of food in pots with an average of $3.3 \mathrm{~cm}$ in height and $3.0 \mathrm{~cm}$ in diameter (Figure 4E).

Geographical distribution (Figure 6): Brazil (Amazonas, Roraima).

Holotype: worker. Label data: BRASIL Amazonas. Itacoatiara, AM-010, km-215. Faz Aruanã. 0302S / 5850W, 24.iv.1994. F.J.Peralta, arastão / Scaptotrigona hylaeana sp. n. Camargo, MS, Det. Camargo, 2009

Examined Material: Paratypes workers (98): BRAZIL: Amazonas: 27 (INPA), BRASIL Amazonas. Itacoatiara, AM-010, km-215. Faz Aruanã. 0302S / 5850W, 24.iv.1994. F.J.Peralta / Scaptotrigona hylaeana sp. n. Camargo, MS, Det. Camargo2009; 53 (INPA), idem except: 5850W, 24.iv.1994. F.J.Peralta, arastão; 1 (MZSP) idem; 1 (RPSP) idem; 1 (MPEG) idem; 1 (ZSM) idem; 11 (INPA), BRA, AM, Manaus, GPA-INPA, 10.xi.2021, Carvalho-Zilse e equipe leg. (30), Enxameação natural; Roraima: 3 (INPA), BRASIL-Roraima, Rio Uraricoera, Ilha de Maraca, 02-13 v. 1987 / Eq.J.A.Rafael, Arm.de Malaise / Scaptotrigona hylaeana sp. n. Camargo, MS, Det. Camargo, 2009.

\section{ACKNOWLEDGEMENTS}

This research was finantially supported by the Governo do Estado do Amazonas, Secretaria de Estado de Desenvolvimento Econômico, Ciência, Tecnologia e Inovação (SEDECTI) and Fundação de Amparo à Pesquisa do Estado do Amazonas (FAPEAM) - Editais POSGRAD e Mulheres na Ciência and by the Coordenação de Aperfeiçoamento de Pessoal de Nível Superior (CAPES) - Finance code 001. DNS thanks for the support of Instituto Federal de Educação, Ciência e Tecnologia do Amazonas (IFAM). JASS received a scholarship from CAPES as a MSc student of the Programa de Pós-Graduação em Entomologia (PPG-Entomologia) of the Instituto Nacional de Pesquisas da Amazônia (INPA); RMOA receive a scholarship FIXAM II from FAPEAM Edital 001/2021. MLO thanks CNPqBrasil for the productivity grant (305150/2020-0). We thank Stefan Schmidt for sending us specimens for this study from Zoologische Staatssammlung München (ZSM). 


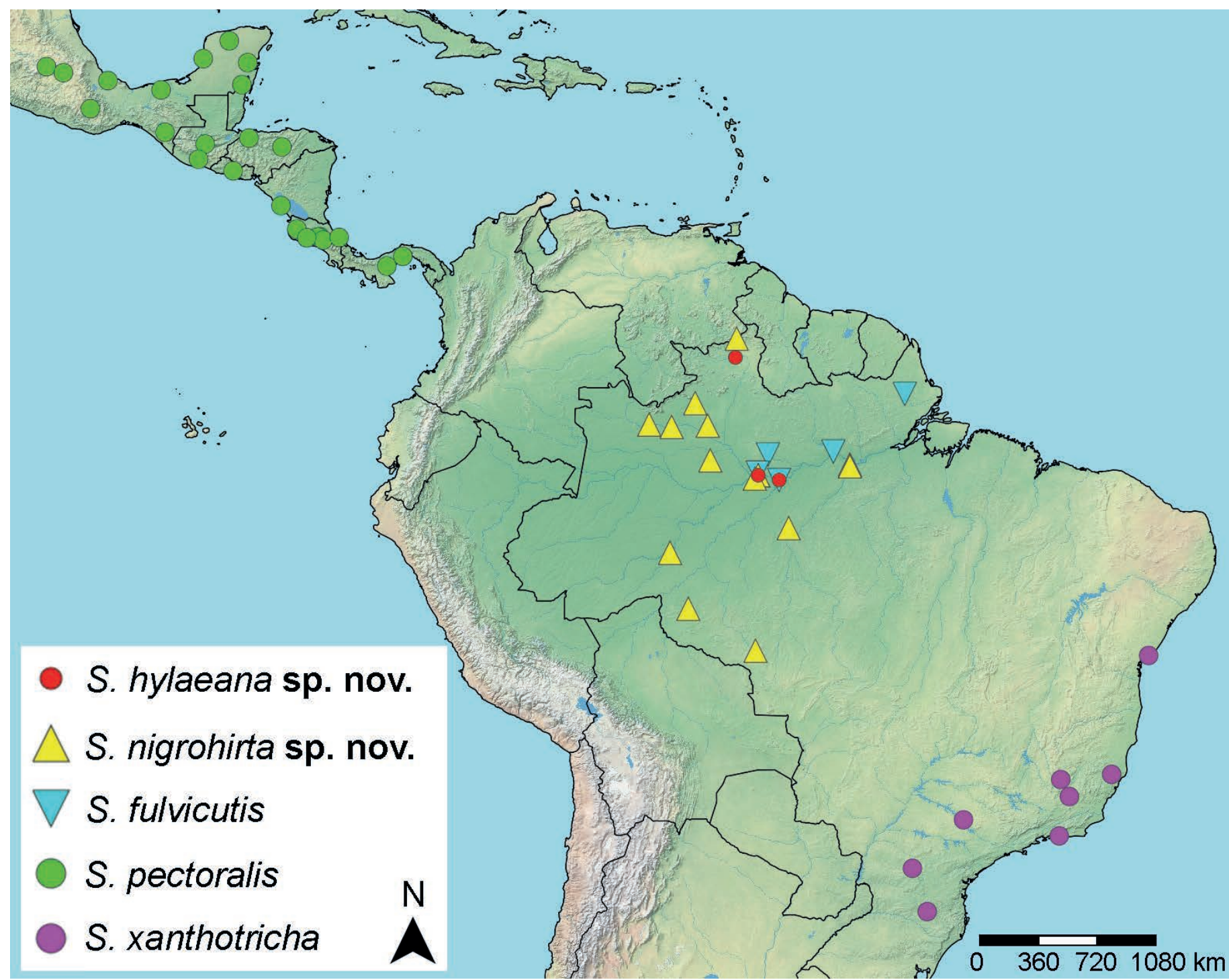

Figure 6. Distribution records of some species of Scaptotrigona Moure, 1942: S. hylaeana sp. nov., S. nigrohirta sp. nov., S. fulvicutis (Moure, 1964), S. pectoralis (Dalla Torre, 1896) and S. xanthotricha Moure, 1950.

\section{REFERENCES}

Barbosa-Costa, K, WE Kerr \& GA Carvalho-Zilse, 2012. Number of malpighian tubules in larvae and adults of stingless bees (Hymenoptera: Apidae) from Amazonia. Neotropical Entomology, 41: 42-5. DOI: https://doi.org/10.1007/ s13744-011-0017-5

Barbosa-Costa, K \& GA Carvalho-Zilse, 2013. Processo de oviposição da abelha da Amazônia Scaptotrigona xanthotricha Moure, 1950, pp. 91-106. In: Bermudéz, EGC, BR Teles \& RLF Keppler (Eds.). Entomologia na Amazônia Brasileira: Volume 2. Editora INPA.

Baumgartner, DL \& DW Roubik, 1989. Ecology of Necrophilous and Filth-Gathering Stingless Bees (Apidae: Meliponinae) of Peru. Journal of the Kansas Entomological Society, 62: 11-22.

Camargo, JMF, 1994. Biogeografia de Meliponini (Hymenoptera, Apidae, Apinae): a fauna amazônica. Anais do Encontro sobre Abelhas de Ribeirão Preto, SP. Ribeirão Preto, USP, 1: 46-59.

Camargo, JMF \& SRM Pedro, 2013. Meliponini Lepeletier, 1836. In: Moure, JS., D Urban; GAR Melo (Eds.). Catalogue of Bees (Hymenoptera, Apoidea) in the Neotropical Region. Avaliable in: <http://moure.cria.org.br/catalogue>. [Access: 22.v.2020].

Camargo JMF \& DA Posey, 1990. O conhecimento dos Kayapó sobre as abelhas sociais sem ferrão (Meliponidae, Apidae, Hymenoptera): notas adicionais. Boletim do Museu Paraense Emílio Goeldi, Série Zoologia, 6: 17-42.

Camargo, JMF \& DW Roubik, 1991. Systematics and bionomics of the apoid obligate necrophages: the Trigona hypogea group (Hymenoptera: Apidae; Meliponinae). Biological Journal of the Linnean Society, 44: 13-39. DOI: https://doi.org/10.1111/j.1095-8312.1991.tb00604.x

Camargo, JMF, WE Kerr \& CR Lopes, 1967. Morfologia externa de Melipona (Melipona) marginata Lepeletier (Hymenoptera, Apoidea). Papéis Avulsos de Zoologia, 20, 229-258.

Carvalho-Zilse, GA, 2013. Produção de polinizadores para a agricultura na Amazônia, pp. 19-26. In: Noda, H, LAG Souza \& DFS Filho (Eds.). Pesquisas agronômicas para a agricultura sustentável na Amazônia central. Nerua/CSAS/ INPA.

Coimbra Jr., CEA, 1985. Estudos de ecologia humana entre Suruí do Parque Indígena Aripuanã, Rondônia. Aspectos alimentares. Boletim do Museu Paraense Emílio Goeldi Antropologia, 2: 57-87. DOI: https://doi.org/10.1590/ s0101-81751983000200001

Cortopassi-Laurino, M, VL Imperatriz-Fonseca, DW Roubik, A Dollin, T Heard, I Aguilar, GC Venturieri, C Eardley \& P Nogueira-Neto, 2006. Global meliponiculture: challenges and opportunities. Apidologie, 37: 175-292. DOI: https://doi.org/10.1051/apido:2006027

Costa, KB, 2010. Multiplicações em condições experimentais, caracterização físico-química e nutricional do mel, produtividade de mel e pólen e indução da produção in vitro de rainhas de Scaptotrigona xanthotricha Moure, 1950 (Hymenoptera: Apidae: Meliponina) na Amazônia. (PhD in Biological Sciences - Entomology). Instituto Nacional de Pesquisas da Amazônia. 
Costa-Neto, DJ, MS Valadares, ES Silva-Costa \& JN Souto, 2016. Levantamento da fauna de abelhas sem ferrão no estado do Tocantins. Acta Biológica Catarinense, 3: 138-148. DOI: https://doi.org/10.21726/abc.v3i2.258

Cruz-Landim, C, FC Abdalla \& LF Gracioli-Vitti, 2006. Class III glands in the abdomen of Meliponini. Apidologie, 37: 164174. DOI: https://doi.org/10.1051/apido:2006024

Delgado, C \& M Vela, 2012. Las abejas nativas, Melliponas (Hymenoptera: Melliponidae) asociadas al Camu Camu Myrciaria dubia. Folia Amazónica, 21: 77-86. DOI: https://doi.org/10.24841/fa.v21i1-2

Duarte, OMP, FA Gaiotto \& MA Costa, 2014. Genetic differentiation in the stingless bee, Scaptotrigona xanthotricha Moure, 1950 (Apidae, Meliponini): a species with wide geographic distribution in the Atlantic Rainforest. Journal of Heredity, 105: 477-484. DOI: https://doi.org/10.1093/jhered/esu031

Ferreira, GAC, 2020. Camu-Camu (Myrciaria dubia (Kunth) McVaugh) e seus polinizadores: produtividade, diversidade e interações na Amazônia central, Brasil. (Master in Biological Sciences - Botany). Instituto Nacional de Pesquisas da Amazônia.

Ferreira, MFO, R Fraga, EC Barros \& SC Augusto, 2020. Effects of abamectin and acetamiprid pesticides on the survival and behavior of Scaptotrigona aff. xanthotricha (Apidae, Meliponini). Journal of Apicultural Research: 1-8. DOI: https://doi.org/10.1080/00218839.2020.1835262

Françoso, E \& C Arias, 2013. Cytochrome c oxidase I primers for corbiculate bees: DNA barcode and mini-barcode. Molecular Ecology Resources, 13: 844-850. DOI: https://doi.org/10.1111/1755-0998.12135

Kerr, W. E., GA Carvalho \& VA Nascimento, 1996. Abelha Uruçu: biologia, manejo e conservação. Ed. Fundação Acangaú, Paracatu, MG.

Maia, UM, CE Pinto, LS Miranda, BWT Coelho, JES Júnior, RL Raiol, VL Imperatriz-Fonseca \& TC Giannini, 2020. Forest Matrix Fosters High Similarity in Bee Composition Occurring on Isolated Outcrops Within Amazon Biome. Environmental Entomology, 49: 1374-1382. DOI: https://doi.org/10.1093/ee/nvaa115

Michener, CD, 1990. Classification of the Apidae(Hymenoptera). Appendix: Trigona genalis Friese, a hitherto unplaced New Guinea species. University of Kansas Science Bulletin, 54: 75-163.

Michener, CD, 2007. The Bees of the World. The Johns Hopkins University Press. 2nd Ed.

Moure, JS, 1942. Abelhas de Salobra (Hym. Apoidea). Papéis Avulsos, 2: 291-321.

Moure, JS, 1951. Notas sôbre Meliponinae (Hymenopt. Apoidea). Dusenia 1: 25-70.

Nates-Parra, G, 2001. Las Abejas sin Aguijón (Hymenoptera: Apidae: Meliponini) de Colombia. Biota Colombiana, 2: 233-248.

Oliveira, ML, 2002. As abelhas sem ferrão na vida dos seringueiros e dos Kaxinawá do alto rio Juruá, Acre, Brasil, pp. 615-630. In: Cunha MC \& MB Almeida (Eds.). Enciclopédia da Floresta: O alto Juruá: práticas e conhecimento das populações. Companhia das Letras.
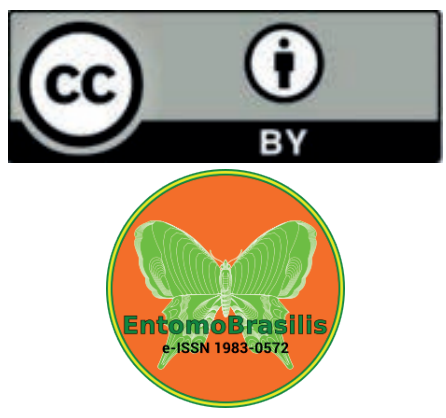

Pedro, SRM, 2014. The stingless bee fauna in Brazil (Hymenoptera: Apidae). Sociobiology, 61: 348-354. DOI: https://doi.org/10.13102/sociobiology.v61i4.348-354

Pires, AP, SMPC Silva, A Pacheco, HHF Azevedo, JRSC Moraes \& DKT Moreira, 2020. Physicochemical profile of honeys from different species of stingless bees from western Pará, Brazilian Amazonia. Brazilian Journal of Development, 6: 1-18. DOI: https://doi.org/10.34117/bjdv6n8-370

Posey, DA, 1982. The Importance of Bees to Kayapó Indians of the Brazilian Amazon. The Florida Entomologist, 65: 452458. DOI: https://doi.org/10.2307/3494679

Posey, DA, 1983. Keeping of stingless bees by the Kayapo' Indians of Brazil. Journal of Ethnobiology, 3: 63-73.

Posey, DA, 1986. Etnoentomologia de tribos indígenas da Amazônia. pp: 251-271. In: Ribeiro, D. (ed.). Suma Etnológica Brasileira. Edição atualizada do Handbook of South American Indians. Petrópolis: Vozes, Finep.

Posey, DA \& JMF Camargo, 1985. Additional notes on the classification and knowledge of stingless bees (Meliponinae, Apidae, Hymenoptera) by the Kayapó Indians of Gorotire, Pará, Brazil. Annals of Carnegie Museum, 54: 247-274.

Rasmussen, C \& SA Cameron, 2010. Global stingless bee phylogeny supports ancient divergence, vicariance, and long distance dispersal. Biological Journal of the Linnean Society, 99: 206-232. DOI: https://doi.org/10.1111/j.10958312.2009.01341.x

Rezende, ACC, ML Absy, MG Ferreira, HA Marinho \& AO Santos, 2019. Pollen of honey from Melipona seminigra merrillae Cockerell, 1919, Scaptotrigona nigrohirta Moure, 1968 and Scaptotrigona sp. Moure, 1942 (Apidae: Meliponini) reared in Sataré Mawé e indigenous communities, Amazon, Brazil. Palynology, 43: 255-267. DOI: https://doi.org/10.10 80/01916122.2018.1458664

Roubik, DW, JA Lobo Segura \& JMF Camargo, 1997. New stingless bee genus endemic to Central Amrican cloudforests: phylogenetic and biogeographic implications (Hymenoptera: Apidae: Meliponini). Systematic Entomology, 22: 67-80.

Silveira, FA, GAR Melo \& EAB Almeida, 2002. Abelhas Brasileiras: Sistemática e Identificação. Belo Horizonte: F. A. Silveira.

Venturieri, GC, 1999. Reproductive ecology of Schizolohiwn Amazonkum huber ex ducke and Sclerolobium Panculatum Vogel (Leg: Caesalpinioidea) and its importance in forestry management projects. In: Anais do Simpósio Silvicultura na Amazônia oriental: contribuições do projeto EMBRAPA/ DFID. Belém, PA, Brasil.

Venturieri, GC \& VL Imperatriz-Fonseca, 2000. Scaptotrigona nigrohirta e Melipona melanoventer (Apidae: Meliponinae): espécies amazônicas com potencialidades para a meliponicultura. In: Anais do IV Encontro sobre Abelhas. Ribeirão Preto, SP, Brasil.

Viana, APS, D Pauletto, JRV Gama, AP Pires, HHF Azevedo \& A Pacheco, 2021. Meliponiculture in agroforestry systems in Belterra, Pará, Brazil. ACTA Apicola Brasilica, 9: 1-9. DOI: https://doi.org/10.18378/aab.v9i0.7913

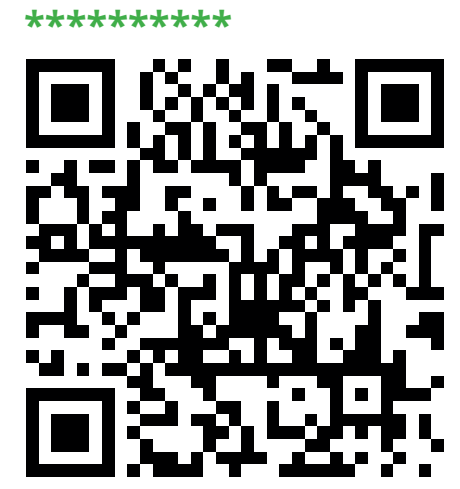

